Navigation Physics 2(2) (2020)
Navigation Physics
Journal of Physics Education

\title{
Pengembangan Media Pembelajaran Komik Fisika Materi Pokok Pengukuran Untuk Siswa SMA Negeri 1 Compreng
}

\author{
Rendi $^{1^{*}}$, Sumaryati ${ }^{2}$, Popi Purwanti ${ }^{3}$ \\ ${ }^{1}$ SMAN 1 Compreng Subang \\ ${ }^{2}$ Universitas Indraprasta PGRI \\ *E-mail: popi.purwanti20@gmail.com
}

\begin{tabular}{|c|c|}
\hline Info Artikel & Abstract \\
\hline $\begin{array}{l}\text { Sejarah Artikel: } \\
\text { Diterima November } 2020 \\
\text { Disetujui November } 2020 \\
\text { Dipublikasikan Desember } 2020\end{array}$ & $\begin{array}{l}\text { The purpose of this study is to develop learning media for physics comics } \\
\text { on the subject matter of measurement for class X students, to know the } \\
\text { quality of physics comics in the developed measurement material for class } \\
\text { X students at SMAN } 1 \text { Compreng, and to know the students' responses to } \\
\text { physics comics on the developed measurement material. This research is } \\
\text { development research by conducting product analysis to be developed, } \\
\text { developing initial products, expert validation and revisions, small-scale } \\
\text { field trials and product revisions, and large-scale field trials and final } \\
\text { products. The result of the research is the product developed in the form of } \\
\text { Comic Physics Media, the Main Material of Measurement. The quality of } \\
\text { the physics comic media developed according to media experts is good } \\
\text { with a value of } 3.14 \text {, according to the material experts is very good with a } \\
\text { value of } 3.61 \text {, according to the physics teacher is very good with a value of } \\
3 \text {, } 67.3 \text { ). Student responses to physics comics in limited trials obtained a } \\
\text { percentage of } 93 \% \text { while in large-scale field trials obtained a percentage of } \\
95 \% \text {. Based on the percent of research, this comic is suitable for use as a } \\
\text { physics learning media. }\end{array}$ \\
\hline
\end{tabular}

How to Cite: Rendi, R., Sumaryati., \& Purwanti, P. (2020). Pengembangan Media Pembelajaran Komik Fisika Materi Pokok Pengukuran Untuk Siswa SMA Negeri 1 Compreng. Navigation Physics, 2 (2): 74-83.

\section{PENDAHULUAN}

Berdasarkan hasil wawancara dengan guru mata pelajaran Fisika di Sekolah Menengah Atas Negeri 1 Compreng diperoleh informasi bahwa nilai rata-rata yang didapatkan siswa SMA Negeri 1 Compreng terhadap materi fisika adalah 33,714. Nilai tersebut jauh dibawah rata-rata nilai UN Fisika provinsi Jawa Barat maupun nasional yaitu 67, 49 dan 67,43. Hal ini dibuktikan dengan sedikitnya siswa yang memilih mata pelajaran Fisika dalam ujian nasional. Dari 103 siswa IPA yang ada di sekolah tersebut, di dapatkan 14 siswa yang memilih mata pelajaran UN pilihan Fisika dan selebihnya adalah mata pelajaran UN peminatan yang lainnya. Mata pelajaran Fisika adalah mata pelajaran yang sulit dibandingkan mata pelajaran umum maupun mata pelajaran rumpun IPA lainnya (Samudra, dkk, 2014). Pandangan siswa yang seperti itu di sebabkan karena pada mata pelajaran Fisika terdapat banyak konsep fisika yang abstrak dan sulit untuk dipahami.

Pada materi fisika kelas X ada pembelajaran materi pengukuran. Pengukuran adalah suatu kegiatan membandingkan nilai suatu besaran dengan besaran lain yang ditetapkan sebagai satuan (Sunardi \& Zenab, 2014). Selain itu, siswa di Sekolah Menengah Atas Negeri 1 Compreng belum memiliki buku pedoman belajar yang praktis untuk menunjang kegiatan belajar mandiri di sela-sela kesibukan siswa Sekolah Menengah Atas Negeri 1 Compreng. Untuk mengatasi permasalahan seperti itu, guru harus bisa membuat media pembelajaran alternatif sebagai inovasi dalam kegiatan pembelajarannya (Arsyad, 2013; Niarti, 2017). Namun, kegiatan pembelajaran di Sekolah Menengah Atas Negeri 1 Compreng masih 
jarang menggunakan media alternatif seperti alat peraga, flash, maupun komik fisika. Media pembelajaran alternatif yang akan dikembangkan peneliti yaitu komik fisika materi pengukuran.

Kegiatan pembelajaran adalah proses menyampaikan informasi dari sumber informasi kepada penerima informasi (Huda, 2013). Oleh karena proses pembelajaran merupakan proses komunikasi dan berlangsung pada suatu sistem, maka media pembelajaran menempati posisi yang cukup penting sebagai salah satu komponen sistem (Putri dan Ariyanti, 2015). Media pembelajaran adalah sesuatu yang dapat digunakan untuk menyalurkan pesan dan merangsang terjadinya proses belajar pada pembelajar (siswa), makna media pembelajaran lebih luas dari alat peraga, alat bantu mengajar, media audio visual (Zainal, 2013; Asyar, 2012; Astuti dkk, 2019). Media pembelajaran yang menarik siswa dan mengefektifkan proses belajar (Rumainur, 2016).

Upaya untuk menyikapi masalah tersebut, maka diperlukan media alternatif yang dapat memotivasi minat mereka dalam memahami materi fisika, dapat memvisualisasikan materi fisika yang dianggap abstrak, dapat meningkatkan kemampuan kognitif siswa, dan bersifat praktis (bisa digunakan kapanpun, dimanapun, dan mudah dibawa). Media alternatif yang dapat dikembangkan untuk siswa saat ini adalah media pembelajaran komik. Komik adalah bercerita atau mengungkapkan ide dengan gambar (Darmawan, 2012). Karena media pembelajaran komik dapat meningkatkan kemampuan kognitif siswa dibandingkan dengan siswa yang mempelajari materi fisika dengan menggunakan buku teks (Avrillianti, Budiawanti, dan Jamzuri, 2013). Komik dapat meningkatkan motivasi belajar siswa dapat memvisualisasikan materi fisika yang abstrak dengan gambar, dan bisa dicetak sesuai dengan kebutuhan siswa (Nurohimah, Kurniawan, dan Ashari, 2012).

Penelitian yang dilakukan oleh (Aslamiyah dkk, 2017) menyimpulkan bahwa terdapat banyak komik mengenai ilmu pengetahuan mampu membuat ketertarikan pembacanya untuk mempelajari ilmu pengetahuan dan banyak manfaat menggunakan komik di dalam pendidikan sains yaitu komik sebagai sarana berkomunikasi mengenai ilmu pengetahuan di luar kelas. Tujuan dari penelitian ini yaitu untuk mengembangkan media pembelajaran komik fisika materi pokok pengukuran. Mengetahui kualitas dan respon siswa di SMA Negeri Kabupaten Subang terhadap komik Fisika materi pokok Pengukuran yang dikembangkan.

\section{METODE PENELITIAN}

Penelitian dimulai pada bulan September sampai Desember 2018. Pelaksanaan Penelitian dilakukan di kelas X SMAN 1 Compreng Kab. Subang. Metode Penelitian ini merupakan metode penelitian Research and Development (R\&D), Penelitian pengembangan. Uji coba skala kecil penelitian ini diujikan terhadap 35 siswa X.MIPA. Pada Uji coba skala lapangan besar penelitian ini diujikan kepada 72 siswa X.MIPA.

Model yang digunakan dalam penelitian pengembangan ini adalah model prosedural. Prosedur dalam penelitian pengembangan ini mengadaptasi pada prosedur penelitian pengembangan Puslitjaknov dengan melibatkan lima langkah utama yaitu: (1) Melakukan analisis produk yang akan dikembangkan, (2) Mengembangkan produk awal, (3) Validasi ahli dan revisi, (4) Uji coba lapangan skala kecil dan revisi produk, (5) Uji coba lapangan skala besar dan produk akhir (Puslitjaknov, 2008: 11).

Langkah analisis data penilaian media pembelajaran dilakukan melalui langkah sebagai berikut:

1. Analisa dilakukan seperti pada skala Likert (Widoyoko, 2012). Jawaban angket ini menggunaka skala Guttman berupa data interval atau rasio dikotomi (dua alternatif) dan hasilnya yang berupa jawaban ya atau tidak.

2. Jawaban terhadap respon Positif diberi nilai 1 untuk Ya dan 0 untuk tidak. Sedangkan Jawaban terhadap respon Negatif diberi nilai 0 untuk Ya dan 1 untuk tidak.

3. Setelah data terkumpul kemudian data dianalisis menggunakan persentase seperti pada skala likert.

$$
\begin{aligned}
& N P=\frac{R}{S M} \\
& \text { Keterangan : } \\
& \text { NP : Nilai Persentase } \\
& \mathrm{R}: \text { Skor yang diperoleh } \\
& \mathrm{SM}: \text { Skor maksimal dari aspek yang diharapkan }
\end{aligned}
$$

Jika analisis respon siswa diperoleh hasil persentase Ya di atas 50\%, maka produk berupa media pembelajaran komik fisika dengan materi pokok pengukuran siap digunakan sebagai media pembelajaran 
mandiri. Jika belum, maka produk direvisi sehingga memenuhi kualitas dan layak digunakan sebagai media pembelajaran.

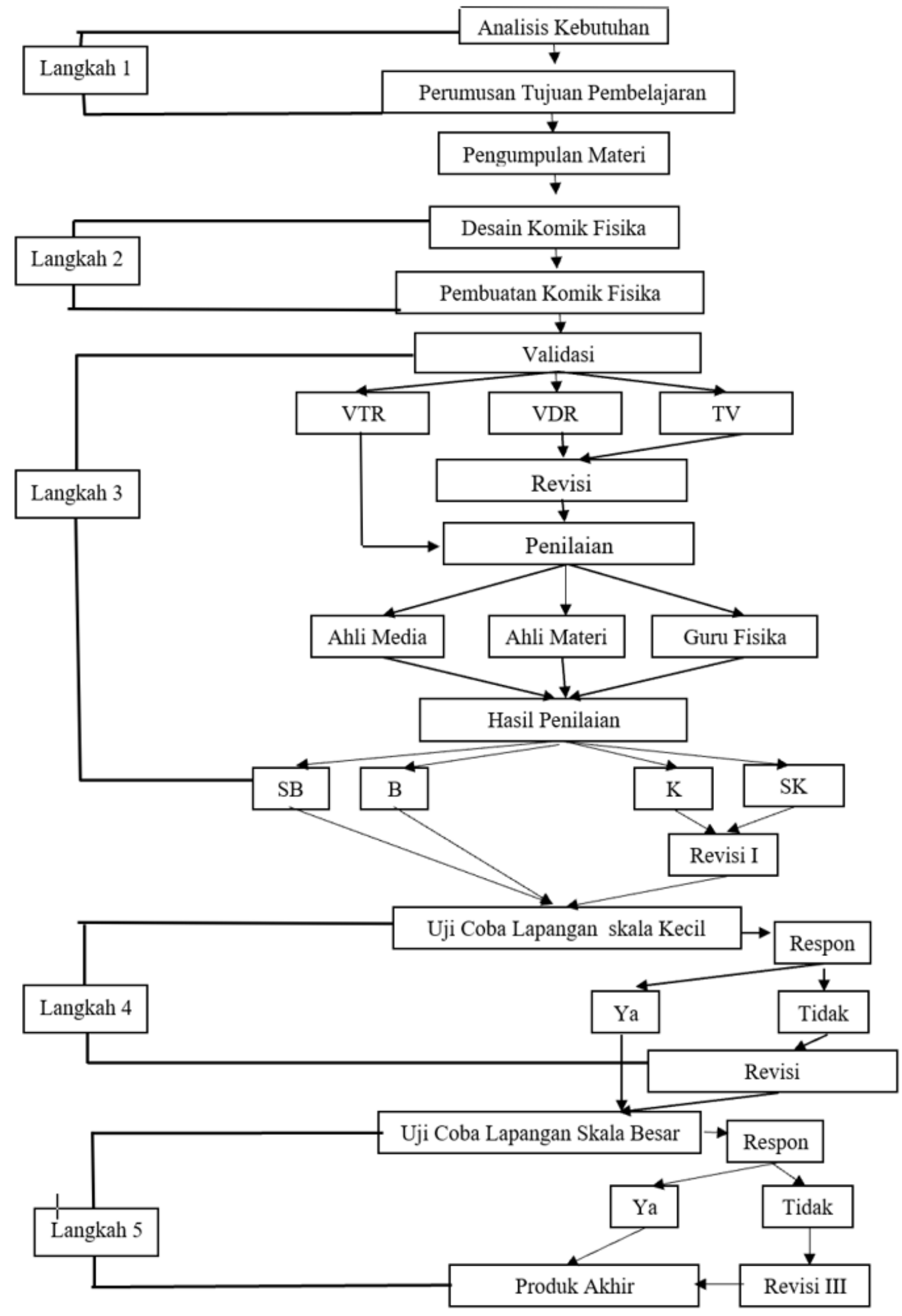

Gambar 1. Skema Penelitian 


\section{HASIL DAN PEMBAHASAN}

Produk yang dikembangkan pada penelitian ini adalah media pembelajaran komik dan rencana pelaksanaan pembelajaran fisika materi pokok pengukuran. Adapun susunan dari produk tersebut adalah sebagai berikut:

a. Halaman Sampul: berisi judul dan gambar yang berkaitan dengan isi komik.

b. Halaman standar kompetensi dan kompetensi dasar.

c. Halaman do'a: berisi do'a sebelum dan sesudah belajar.

d. Daftar isi: berisi tentang nomor urut halaman komponen yang disajikan.

e. Salam tokoh: berisi gambar dan nama tokoh dalam komik fisika.

f. Isi cerita: berisi uraian materi pengukuran yang disajikan dalam bentuk gambar-gambar dalam komik fisika. hasil:

Instrumen penilaian dan produk jadi komik fisika divalidasi oleh 1 validator instrumen, dengan

1) Validator Instrumen

a) Mengganti redaksi penulisan sesuai dengan bahasa baku.

b) Mengganti kisi-kisi respon siswa yang tidak sesuai.

Data Hasil Penilaian Kualitas Produk

Penilaian kualitas produk komik fisika dinilai oleh 3 orang ahli materi, 3 orang ahli media, dan 3 orang guru fisika SMA. Penilaian kualitas secara keseluruhan dinyatakan sangat baik (SB) jika $>3,25 \mathrm{~s} / \mathrm{d}$ 4,0, baik (B) jika $>2,5 \mathrm{~s} / \mathrm{d} 3,25$, tidak baik (TB) jika $>1,75 \mathrm{~s} / \mathrm{d} 2,5$, dan sangat tidak baik (STB) jika 1,0 s/d 1,75 (Widoyoko, 2012).. Data-data yang diperoleh pada tahap penilaian adalah:

a. Penilaian ahli media

Dalam penilaian ahli media, peneliti memilih 3 orang ahli media komik. Kedua penilai ini hanya menilai produk dari segi kualitas komik, hasil dari penilaian tersebut disajikan dalam tabel berikut.

Tabel 1. Data penilaian ahli media

\begin{tabular}{|c|c|c|c|c|c|c|c|c|}
\hline \multirow[b]{2}{*}{ Aspek Penilaian } & \multirow{2}{*}{$\begin{array}{l}\text { Kriteria } \\
\text { Penilaian }\end{array}$} & \multicolumn{3}{|c|}{ Penilai } & \multicolumn{3}{|c|}{$\sum$} & \multirow[t]{2}{*}{ Kategori } \\
\hline & & 1 & 2 & 3 & $\sum$ skor & $\begin{array}{c}\text { Per } \\
\text { Aspek }\end{array}$ & Rata-rata & \\
\hline \multirow{5}{*}{ Anatomi Komik } & 1 & 4 & 4 & 2 & 10 & & & \multirow{5}{*}{ Sangat Baik } \\
\hline & 2 & 3 & 3 & 3 & 9 & & & \\
\hline & 3 & 4 & 2 & 1 & 7 & 49 & 3,26 & \\
\hline & 4 & 4 & 3 & 3 & 11 & & & \\
\hline & 5 & 4 & 4 & 4 & 12 & & & \\
\hline \multirow{3}{*}{$\begin{array}{l}\text { Mutu Gambar dan } \\
\text { Cerita Komik }\end{array}$} & 6 & 4 & 3 & 2 & 9 & & & \multirow{3}{*}{ Baik } \\
\hline & 7 & 4 & 3 & 3 & 10 & 29 & 3,22 & \\
\hline & 8 & 4 & 3 & 3 & 10 & & & \\
\hline \multirow{5}{*}{$\begin{array}{l}\text { Tampilan } \\
\text { Menyeluruh }\end{array}$} & 9 & 4 & 2 & 2 & 8 & & & \multirow{5}{*}{ Baik } \\
\hline & 10 & 4 & 3 & 2 & 9 & & & \\
\hline & 11 & 4 & 2 & 2 & 8 & 44 & 2,93 & \\
\hline & 12 & 4 & 2 & 2 & 8 & & & \\
\hline & 13 & 4 & 4 & 3 & 11 & & & \\
\hline \multicolumn{2}{|c|}{ Jumlah Skor } & 51 & 38 & 32 & 121 & 81 & 3,14 & Baik \\
\hline
\end{tabular}

b. Penilaian ahli materi

Dalam penilaian ahli materi, peneliti memilih 3 orang ahli materi. Hasil dari penilaian tersebut disajikan dalam tabel berikut.

Tabel 2. Data penilaian ahli materi

\begin{tabular}{|c|c|c|c|c|c|c|c|c|c|}
\hline \multirow[b]{2}{*}{ Aspek Penilaian } & \multirow[b]{2}{*}{$\begin{array}{c}\text { Kriteria } \\
\text { Penilaian }\end{array}$} & \multicolumn{4}{|c|}{ Penilai } & \multirow{2}{*}{\multicolumn{2}{|c|}{$\begin{array}{c}\sum_{\text {Per }} \\
\text { Aspek }\end{array}$}} & \multirow[b]{2}{*}{ Rata-rata } & \multirow[b]{2}{*}{ Kategori } \\
\hline & & 1 & 2 & 3 & 4 & & & & \\
\hline \multirow{2}{*}{ Aspek Penulisan } & 1 & 4 & 4 & 4 & 4 & 16 & \multirow{2}{*}{30} & \multirow{2}{*}{3,75} & Sangat Baik \\
\hline & 2 & 3 & 3 & 4 & 4 & 14 & & & \\
\hline $\begin{array}{l}\text { Kebenaran } \\
\text { Konsep }\end{array}$ & 3 & 4 & 4 & 4 & 4 & 16 & 16 & 4 & Sangat Baik \\
\hline Kedalaman & 4 & 3 & 4 & 4 & 3 & 14 & 29 & 3,62 & Sangat Baik \\
\hline
\end{tabular}




\begin{tabular}{|c|c|c|c|c|c|c|c|c|c|}
\hline Konsep & 5 & 3 & 4 & 4 & 4 & 15 & & & \\
\hline \multirow{2}{*}{ Keluasan Konsep } & 6 & 2 & 3 & 3 & 3 & 11 & \multirow{2}{*}{26} & \multirow{2}{*}{3,25} & \multirow[t]{2}{*}{ Baik } \\
\hline & 7 & 3 & 4 & 4 & 4 & 15 & & & \\
\hline \multirow{3}{*}{ Kebahasaan } & 8 & 3 & 4 & 3 & 4 & 14 & & & \multirow{3}{*}{ Sangat Baik } \\
\hline & 9 & 3 & 3 & 3 & 4 & 13 & 41 & 3,42 & \\
\hline & 10 & 3 & 4 & 4 & 3 & 14 & & & \\
\hline \multicolumn{2}{|c|}{ Jumlah Skor } & 31 & 37 & 37 & 37 & 142 & 142 & 3,61 & Sangat Baik \\
\hline
\end{tabular}

c. Penilaian guru Fisika SMA

Dalam penilaian guru Fisika SMA, peneliti memilih 3 penilai yang bekerja sebagai guru Fisika SMAN 1 Compreng di Kabupaten Subang. Data penilaian oleh guru Fisika SMA disajikan dalam tabel berikut.

Tabel 3. Data penilaian guru fisika SMA

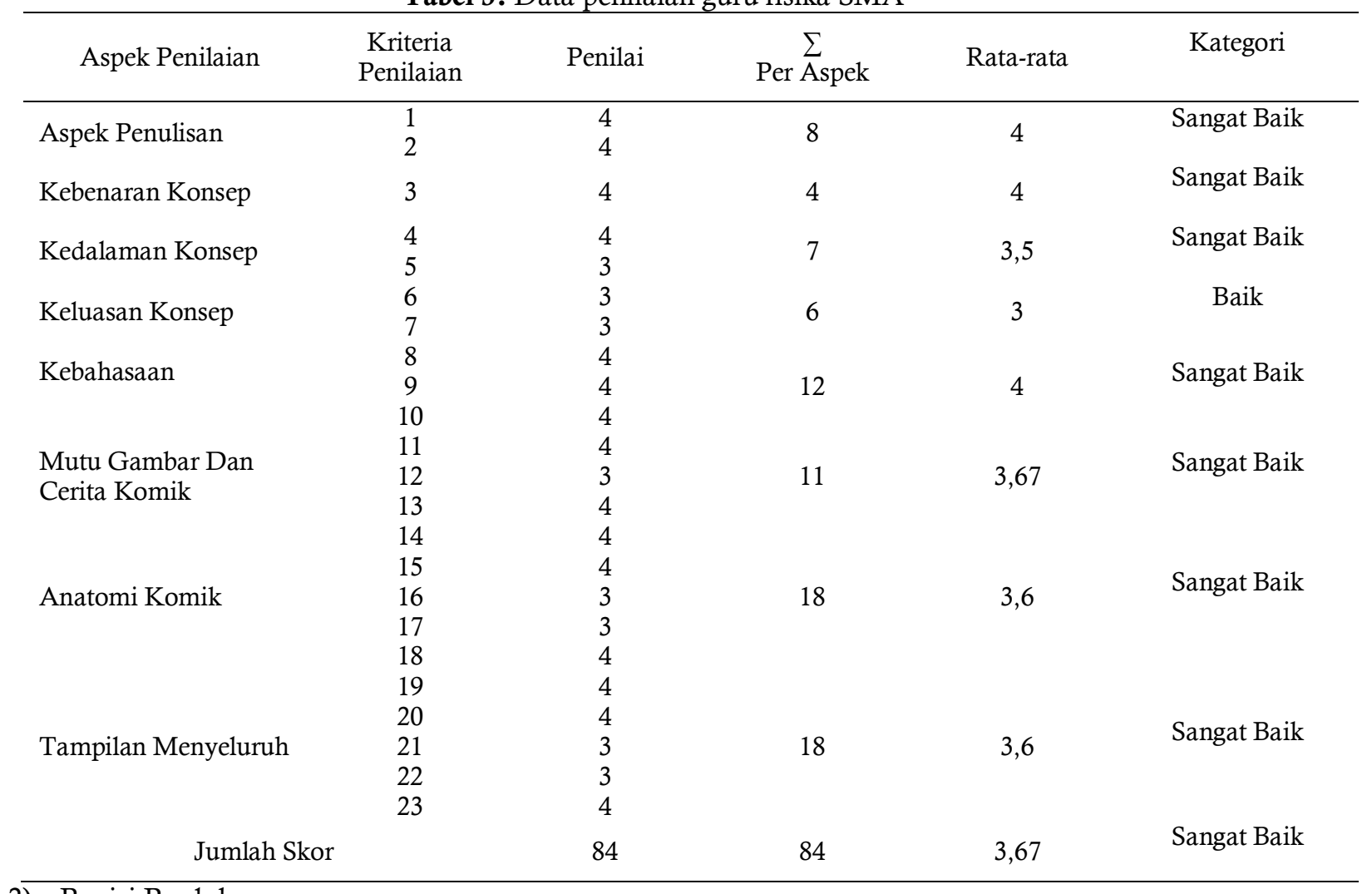

2) Revisi Produk

Revisi produk dilakukan supaya produk yang dikembangkan semakin berkualitas dan dapat diterima oleh siswa. Revisi produk pada penelitian ini seharusnya dilakukan sebanyak 3 kali. Ketiga revisi tersebut yaitu, setelah penilaian para ahli, setelah uji coba skala kecil, dan setelah uji coba skala besar. Berdasarkan hasil penilaian yang telah dilakukan terhadap media pembelajaran komik fisika ini dinyatakan memiliki penilaian yang Sangat Baik (SB) dari ahli materi, ahli media, dan guru SMA sedangkan penilaian Baik diperoleh dari penilaian ahli media dengan nilai 3,14, hasil ini diperoleh karena media komik fisika yang dibuat memiliki kualitas yang standard dan belum sebaik komik yang dibuat oleh komikus-komikus profesional yang telah beredar di masyarakat. Pada penilaian ahli materi mendapatkan kategori Sangat Baik (SB) dengan nilai 3,61, hasil ini didapatkan karena media komik fisika dibuat dengan konten materi fisika yang baik. Pada penilaian guru fisika SMA mendapatkan kategori Sangat Baik (SB) sekaligus dengan hasil tertinggi dibandingkan dengan penilaian para ahli yaitu 3,67. Hasil tersebut dikarenakan intrumen penilaian yang digunakan oleh guru SMA dan sudah bisa digunakan sebagai media pembelajaran untuk siswa di SMAN 1 Compreng menurut guru fisika. Sedangkan hasil penilaian kualitas komik fisika dari ahli media paling rendah yaitu 3,14, ini dikarenakan mutu gambar dan kualitas komik yang dibuat oleh peneliti belum terlalu baik dan memerlukan beberapa revisi. 
Produk komik fisika ini berisi mengenai materi pokok pengukuran kelas X pada semester ganjil dengan halaman judul sebagai berikut.

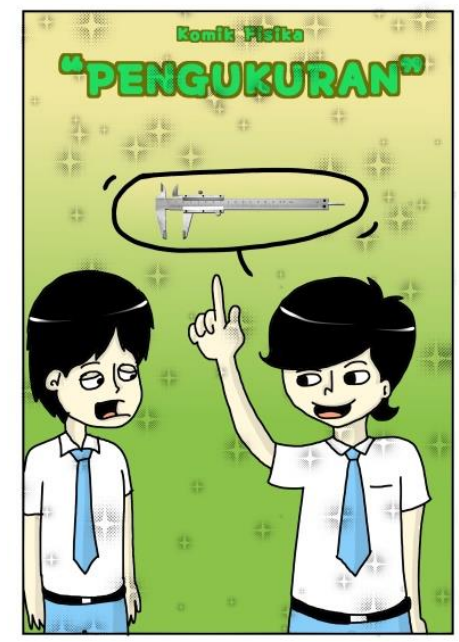

Gambar 3. Cover komik fisika Sumber: Dokumen pribadi berikut.

Daftar isi komik fisika pada pokok pengukuran kelas X pada semester ganjil dengan tampilan sebagai

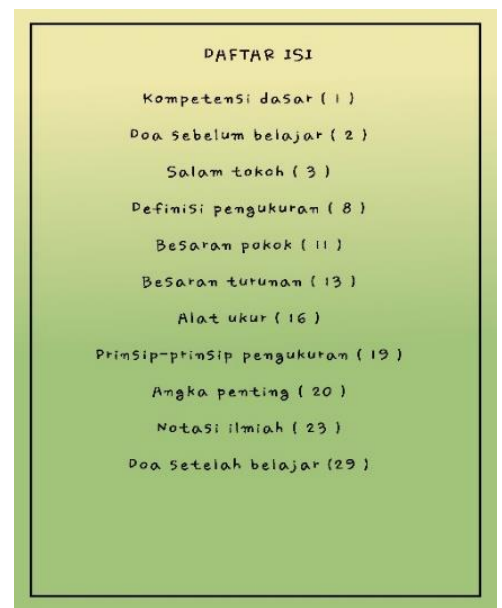

Gambar 4. Daftar isi komik fisika

Sumber: Dokumen pribadi

Awal cerita komik, yaitu seorang siswa yang bernama Daliman dan Alvaro yang mendapatkan nilai hasil belajar fisika yang kurang memuaskan. Kemudian secara tiba-tiba mereka bertemu dengan pemuda yang mengaku sebagai Profesor D mengajarkannya mengenai ilmu fisika seperti Pada Gambar 5. 


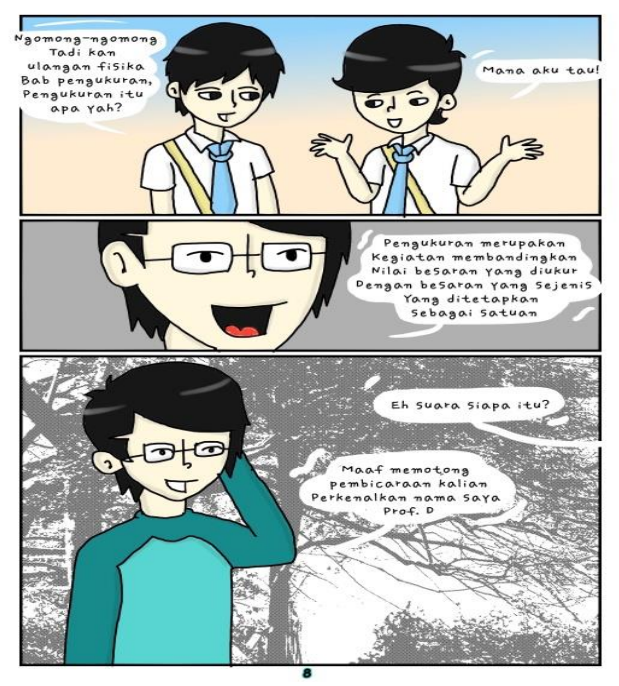

Gambar 5. Komik fisika hal 8 Sumber: Dokumen pribadi

Produk akhir penelitian pengembangan yang dilakukan adalah tersusunnya komik fisika materi pokok pengukuran untuk siswa untuk SMA kelas X. Komik fisika ini dikembangkan dari Kompetensi Dasar yaitu menerapkan prinsip-prinsip pengukuran besaran fisis, ketepatan, ketelitian, dan angka penting, serta notasi ilmiah. Komik fisika ini berjudul "Komik Fisika Pengukuran" yang didalamnya berisi 3 submateri yaitu (1) Besaran dan satuan; (2) Alat ukur, dan (3) Penyajian hasil pengukuran. Komik tersebut dicetak berwarna dengan ukuran kertas A5 yang memuat 30 halaman.
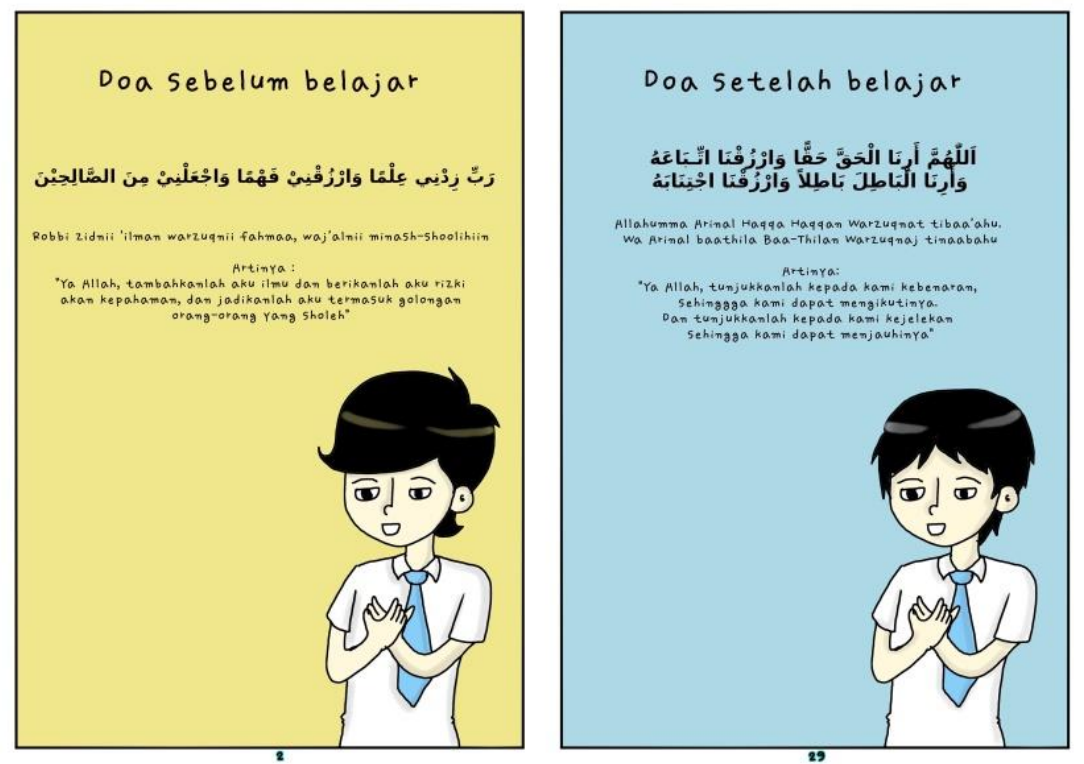

Gambar 6. Komik fisika hal 2 dan 29 Sumber: Dokumen pribadi

Produk akhir komik fisika ini berisi materi fisika yang menyisipkan nilai-nilai islami dengan tujuan supaya siswa bisa belajar dengan komik tersebut secara mandiri maupun kelompok kapanpun dan dimanapun karena tidak mengesampingkan pendidikan karakter, khususnya karakter islami.

3) Analisis Kualitas Produk

Kualitas produk pada penelitian ini diukur menggunakan angket penilaian dengan memberi tanda chek list. Data yang diperoleh berupa data kuantitatif dengan variasi skor jawaban 4 untuk jawaban sangat baik (SB), 3 untuk jawaban baik (B), 2 untuk jawaban tidak baik (TB), dan 1 untuk jawaban sangat tidak 
baik (STB). Berdasarkan hasil penilaian yang telah dilakukan terhadap 3 ahli media, 3 ahli materi, dan 3 guru fisika SMA Negri 1 Compreng.

Kualitas media komik fisika yang telah dikembangkan menurut para ahli media adalah Baik (B) dengan skor 3,14. Kualitas tiap aspeknya yaitu, untuk aspek anatomi komik termasuk kategori Sangat Baik (SB) sekaligus memiliki skor yang tertinggi diantara aspek lainnya dengan skor 3,26, aspek mutu gambar dan cerita komik termasuk kategori Baik (B) yaitu 3,22, dan aspek tampilan menyeluruh termasuk kategori Baik (B) sekaligus aspek dengan skor terendah yaitu 2,93.

Kualitas media komik fisika yang telah dikembangkan menurut para ahli materi adalah Sangat Baik (SB) dengan skor 3,61. Kualitas tiap aspeknya yaitu, untuk aspek penulisan termasuk kategori Sangat Baik (SB) dengan skor 3,75, aspek kebenaran konsep termasuk kategori Sangat Baik (SB) sekaligus memiliki skor yang tertinggi diantara aspek lainnya dengan skor 4,00, aspek kedalaman konsep termasuk kategori Sangat Baik (SB) sekaligus memiliki skor aspek tertinggi yaitu 3,62, aspek keluasan konsep termasuk kategori Baik (B) sekaligus memiliki skor terendah yaitu 3,25, dan aspek kebahasaan termasuk kategori Sangat Baik (SB) dengan skor 3,42.

Kualitas media komik fisika yang telah dikembangkan menurut guru fisika SMA adalah Sangat Baik (SB) dengan skor 3,67. Kualitas tiap aspeknya yaitu, aspek penulisan, Kebenaran konsep, dan kebahasaan termasuk kategori Sangat Baik (SB) sekaligus aspek dengan skor tertinggi dengan skor 4,00, aspek kedalaman konsep termasuk kategori Sangat Baik (SB) yaitu 3,5, aspek keluasan konsep termasuk kategori Baik (SB) sekaligus aspek dengan skor terendah yaitu 3,00, aspek mutu gambar dan cerita komik termasuk kategori Sangat Baik (SB) dengan skor 3,67, aspek anatomi komik termasuk kategori Sangat Baik (SB) dengan skor 3,60, aspek tampilan menyeluruh termasuk kategori Sangat Baik (SB) dengan skor 3,60 .

4) Analisis Hasil Uji Coba Lapangan Skala Kecil

Hasil uji coba lapangan skala kecil terhadap pengembangan media pembelajaran komik fisika menurut 35 siswa SMAN 1 Compreng secara keseluruhan diperoleh persentase 93\%. Kualitas setiap aspeknya yaitu, untuk aspek penulisan diperoleh persentase $100 \%$ dan termasuk aspek dengan nilai persentase tertinggi, aspek keluasan konsep diperoleh persentase $77 \%$ dan termasuk aspek dengan nilai persentase terendah, aspek kebahasaan diperoleh persentase 97\%, aspek keterlaksanaan diperoleh persentase $96 \%$, aspek mutu gambar diperoleh persentase 97\%, dan aspek tampilan menyeluruh diperoleh persentase $92 \%$.

\section{5) Analisis Hasil Uji Coba Lapangan Skala Besar}

Hasil uji coba lapangan skala besar terhadap pengembangan media pembelajaran komik fisika menurut 72 siswa SMAN 1 Compreng secara keseluruhan diperoleh persentase $95 \%$ hasil ini mengalami peningkatan terhadap hasil uji coba lapangan skala kecil yaitu 93\%. Kualitas setiap aspeknya yaitu, untuk aspek penulisan diperoleh persentase $98 \%$ aspek ini mengalami penurunan $2 \%$ terhadap hasil uji coba lapangan sebelumnya yaitu 100\% dan termasuk aspek dengan nilai persentase tertinggi. Aspek keluasan konsep diperoleh persentase $90 \%$ hasil ini mengalami kenaikan yang paling signifikan diantara aspek lainnya yaitu $13 \%$ terhadap hasil uji coba lapangan sebelumnya yaitu $77 \%$, aspek kebahasaan diperoleh persentase $96 \%$ hasil ini mengalami penurunan 1\% terhadap hasil uji coba lapangan sebelumnya yaitu $97 \%$, aspek keterlaksanaan diperoleh persentase $92 \%$ hasil ini mengalami penurunan $4 \%$ terhadap hasil uji coba lapangan sebelumnya yaitu 96\%, aspek tampilan menyeluruh diperoleh persentase $96 \%$ hasil ini mengalami kenaikan $4 \%$ terhadap hasil uji coba lapangan sebelumnya yaitu $92 \%$.

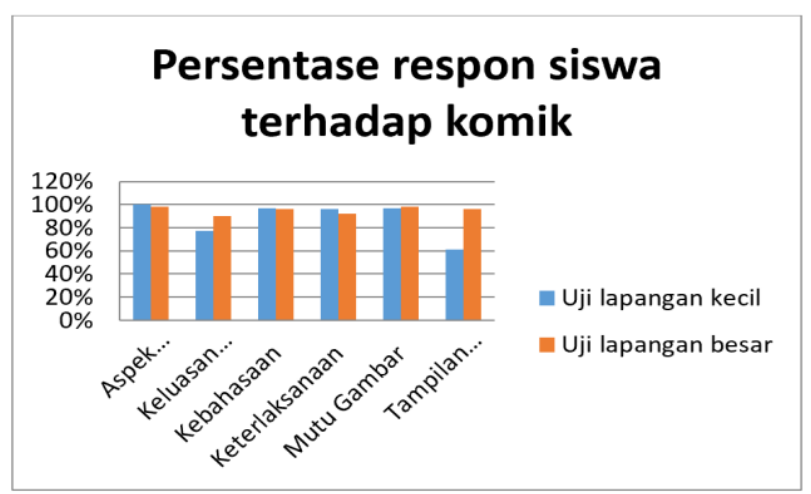

Gambar 2. Grafik persentase respon siswa Sumber: Dokumen pribadi 
Berdasarkan perbandingan respon siswa uji coba lapangan skala kecil dan uji coba lapangan skala besar pada gambar 2, didapatkan data bahwa pada uji coba luas mengalami kenaikan pada aspek, keluasan konsep, mutu gambar, dan tampilan menyeluruh. Sedangkan pada aspek penulisan, kebahasaan, dan keterlaksanaan mengalami penurunan, dan aspek yang memiliki perubahan persentase penilaian tertinggi terdapat pada aspek tampilan menyeluruh.

\section{PENUTUP}

Simpulan yang dapat diambil dari penelitian yang dilakukan adalah Telah berhasil dikembangkan produk berupa komik fisika dengan materi pokok pengukuran untuk siswa SMA Negeri 1 Compreng. Kualitas media komik fisika yang telah dikembangkan menurut para ahli media adalah Baik (B) dengan nilai 3,14. Menurut para ahli materi dan guru fisika SMA adalah Sangat Baik (SB) dengan nilai 3,61 dan 3,67. Respon siswa terhadap komik fisika dengan materi pokok pengukuran pada uji lapangan skala kecil diperoleh persentase 93\% (Ya) sedangkan pada uji lapangan skala besar diperoleh persentase $95 \%$ (Ya). Berdasarkan analisis persentasenya sehingga komik fisika dengan materi pokok pengukuran layak untuk dijadikan media pembelajaran fisika.

Adapun saran yang penulis dapat sampaikan adalah peneliti mengharapkan hasil penelitian berupa komik fisika dengan materi pokok pengukura untuk siswa SMA bisa menjadi bahan informasi untuk mengadakan penelitian lebih lanjut mengenai komik terhadap materi fisika yang lain, dengan model komik yang beragam, dan dengan cerita yang lebih menarik.

\section{UCAPAN TERIMA KASIH}

Pada kesempatan ini, izinkan saya menyampaikan rasa hormat dan ucapan terima kasih kepada semua pihak yang telah memberikan bantuan dan dorongan kepada kami dalam menyelesaikan artikel penelitian ini, terutama kepada; Prof. Dr. H. Sumaryoto selaku Rektor Universitas Indraprasti PGRI Jakarta, Kepala Sekolah, Guru Fisika, dan Siswa SMAN 1 Compreng.

Saya mohon maaf apabila terdapat beberapa kekeliruan dikemudian hari dari artikel ini, baik dari segi isi maupun penulisannya. Karenanya, penulis mengharapkan kritik serta saran yang membangun dari para pembaca. Saya berharap semoga artikel ini dapat menjadi manfaat dan sarana pembelajaran terhadap pembaca.

\section{DAFTAR PUSTAKA}

Aslamiyah, L., Masturi., Nugroho, S. E. (2017). Pengembangan Media Pembelajaran Komik Fisika Berbasis Integrasi-Interkoneksi Nilai-Nilai Alquran. Unnes Physics Education Journal, 6 (3), 44-52.

Asyar, R. (2012). Kreatif Mengembangkan Media Pembelajaran. Jakarta: Gunung Persada Press.

Astuti, I. A. D., Dewati, M., Okyranida, I. Y., \& Sumarni, R. A. (2019). Pengembangan media smart powerpoint berbasis animasi dalam pembelajaran fisika. Navigation Physics: Journal of Physics Education, 1(1), 12-17.

Arsyad, A. (2013). Media pembelajaran. Jakarta : Rajagrafindo Persada.

Avrillianti, H., Budiawanti, S., dan Jamzuri. (2013). Penerapan media komik untuk pembelajaran fisika model kooperatif dengan metode diskusi pada siswa SMPN 5 Surakarta kelas VII tahun ajaran 2011/2012 materi gerak. Jurnal Pendidikan Fisika Universitas Sebelas Maret

Darmawan, H. (2012). How to make comics menurut para master komik dunia. Yogyakarta: Plotpoint.

Huda, M. (2013). Model-Model Pengajaran dan Pembelajaran. Yogyakarta: Pustaka Pelajar.

Niarti, N. (2017). Pengembangan bahan ajar yang berbasis multimedia interaktif pada materi menyimak untuk siswa kelas VI sekolah dasar. Bandar Lampung: Universitas Lampung.

Nurohimah, S., Kurniawan, E. S., dan Ashari. (2012). Pemanfaatan kartun fisika sebagai media pembelajaran untuk meningkatkan motivasi belajar pada sswa kelas VII MTsN Purworejo. Purworejo: Universitas Muhammadiyah Purworejo.

Puslitjaknov. (2008). Metode penelitian pengembangan. Jakarta: Puslitjaknov Balitbang Depdiknas.

Putri, D. Y. K. P., dan Ariyanti, G. (2015). Pengembangan komik matematika sebagai media pembelajaran berbasis pendidikan karakter pada materi perkalian bilangan bulat sekolah dasar. ISSN: 977-2442-8780-11.

Rumainur. (2016). Pengembangan media ajar berbasis multimedia autoplay studio 8 dalam pembelajaran sejarah kebudayaan islam kelas XI MA Bilingual Batu Malang. Malang: UIN Maulana Malik Ibrahim. 
Samudra, G., Suastra, M., \& Suma, M. (2014). Permasalahan-Permasalahan Yang Dihadapi Siswa SMA Di Kota Singaraja Dalam Mempelajari Fisika. Jurnal Pendidikan Dan Pembelajaran IPA Indonesia, $4(1)$.

Sunardi, dan Zenab, S. (2014). Fisika untuk SMA/MA kelas X peminatan. Bandung: Yrama Widya. Widoyoko, E., P., S., (2012). Teknik penyusunan instrumen penelitian. Yogyakarta: Pustaka Belajar.

Zainal, A. (2013). Model-model, Media, dan Strategi Pembelajaran Kontekstual. Bandung: Yrama Widya. 